doi http://dx.doi.org/10.18542/rmi.v15i24.9921

Margens: Revista Interdisciplinar | e-ISSN:1982-5374 | V. 15 | N. 24 | Jun., 2021, pp. 21-45.

\title{
NOMES DO POSSÍVEL: AUTÊNTICA LEMBRANÇA E ESTUDO SEQUENCIAL DAS POLÍTICAS AUTONÔMICAS NO EXTREMO NORTE DO URUGUAI
}

\author{
NAMES OF THE POSSIBLE: AUTHENTIC MEMORIES AND SEQUENTIAL STUDY OF \\ AUTONOMOUS POLITICS IN THE EXTREME NORTH OF URUGUAY
}

\begin{abstract}
Resumo: No ano de 2015, meus interlocutores no movimento popular dos cortadores de canade-açúcar do norte uruguaio enunciavam seus propósitos políticos em referência a um conjunto de palavras emblemáticas que, segundo eles, indicariam a existência de uma antiga "autonomia" passível de ser atualizada no tempo presente. Argumento que esse tipo de recordação é da ordem das "autênticas lembranças" (Walter Benjamin). Nelas, está em jogo a hipótese segundo a qual um acontecimento passado pode ser redescoberto à luz das inquietações atuais que o transformam em objeto de atenção política. Testo essa hipótese mediante uma "análise sequencial da política" (Sylvain Lazarus). Selecionei algumas palavras que mobilizaram a atenção política dos meus interlocutores para, em seguida, submergir-me nas formas de consciência que outrora elas sustentaram. Finalizo o artigo refletindo sobre como um processo político contemporâneo pode revalorizar as experiências autonômicas pretéritas, expondo-nos ao que Benjamin denominaria uma "cristalização em mônada" do tempo da emancipação.
\end{abstract}

Palavras-chave: Autonomia. Lembrança, Política. Movimento popular. Uruguai.

\section{Alex Martins MORAES (CONICET) ${ }^{1}$}

Abstract: My interlocutors of the sugarcane cutters popular movement of NorthernUruguay enunciated their political purposes by referring to a set of emblematic words that, according to them, point to the existence of an old-time 'autonomy' that could nowadays be actualized. This kind of perspective regarding the past belongs to the realm of 'authentic memories' (Walter Benjamin) and raise the hypothesis that a past event can be rediscovered in light of current concerns that make it an object of political attention. I verify this hypothesis through a 'sequential analysis of politics' (Sylvain Lazarus). I select some words that capture the attention of my interlocutors and then I immerse myself in the forms of consciousness that such words once held. Finally, I reflect on how a contemporary political process can give us access to an oldtime autonomic experience, exposing us to what Benjamin would call 'crystallization in monad' of the time of emancipation.

Keywords: Autonomy. Memory. Politics. Popular movement. Uruguay

\footnotetext{
1 Doutor em Antropologia pela Escuela Interdisciplinaria de Altos Estudios Sociales da Universidad de San Martín, Buenos Aires, Argentina. É professor do Consejo Nacional de Investigaciones Científicas y Técnicas, no Campus Comum - Universidade Livre.E-mail: alexmartinsmoraes@gmail.com
} 
As politicas estão sempre em busca dos rastros da politica.

Sylvain Lazarus (2013, p. 177)

\section{INTRODUÇÃO}

Para os meus interlocutores no movimento popular canavieiro da cidade de Bella Unión, situada no extremo norte do Uruguai, o passado eram palavras fragmentárias que se prestavam à especulação intensiva. A recuperação dessas palavras em meio às lutas do tempo presente assegurava uma conexão entre antigas apostas militantes e a ativação de novas mobilizações coletivas, que pretendiam atualizar sob outros termos a potência política experimentada pelas lutas de outrora. Nas palavras herdadas dos combates arrefecidos, a consciência militante sondava os rastros de um movimento essencial cuja repetição poderia, quem sabe, abrir a conjuntura vigente para a intervenção criadora da política. Esse movimento, que meus interlocutores chamavam de "autonomia", seria a fonte original de algumas palavras muito especiais que, ao invés de denotar um objeto, evocavam o gesto, ou melhor, a atitude que as tornara disponíveis para a especulação das gerações futuras. Neste artigo, as palavras em questão serão pensadas como "nomes", ou seja, como vocábulos que designam sem significar. A função principal do nome é iluminar um processo, uma forma de ser, um devir, um modo de transformar-se que se presta à lembrança e à imitação, ainda que seja irrepetível em seu conteúdo específico.

No ano de 2015, os dirigentes do movimento sindical dos cortadores de cana-de-açúcar de Bella Unión estavam procurando nos indícios de velhas lutas populares a inspiração para definir seu próprio espaço de autonomia coletiva diante dos projetos de desenvolvimento rural impulsionados, desde 2006, por sucessivos governos nacionais da Frente Ampla ${ }^{2}$. À época de meu trabalho de campo $^{3}$, os militantes da Unión de Trabajadores Azucareros de Artigas (UTAA) - o sindicato local dos cortadores de cana - dispunham-se a radicalizar as políticas fundiárias do governo nacional no horizonte do que eles denominavam "uma reforma agrária real". Adjetivar a reforma agrária como "real" significava contrapô-la às tímidas políticas de distribuição de terras que o poder público vinha empreendendo desde 2007 no norte do país. Tais políticas garantiram que algumas famílias de

\footnotetext{
${ }^{2}$ A Frente Ampla (Frente Amplio) é uma coalizão que reúne os principais partidos da esquerda e da centro-esquerda uruguaias. Em 2004, essa força política venceu as eleições presidenciais e deu início a uma sucessão ininterrupta de três mandatos à frente do Poder Executivo. Nas eleições de 2004, Tabaré Vázquez, o candidato frenteamplista à presidência da República, recebeu forte adesão dos sindicalistas de Bella Unión e comprometeu-se a fortalecer a agroindústria canavieira dessa cidade.

${ }^{3}$ A pesquisa que deu origem ao presente artigo desenvolveu-se no marco de meus estudos de doutorado em Antropologia Social e recebeu financiamento do Consejo Nacional de Investigaciones Científicas y Técnicas (CONICET - Argentina). 
cortadores de cana recebessem parcelas cultiváveis do Instituto Nacional de Colonização (INC) ${ }^{4}$ para produzir matéria prima destinada a abastecer a usina açucareira local, de propriedade da empresa pública Alcoholes del Uruguay Sociedad Anónima (ALUR) ${ }^{5}$. Contudo, meus interlocutores não estavam convencidos das políticas agrárias do governo nacional porque elas tendiam a circunscrever a distribuição da terra aos imperativos e às necessidades da indústria. Desse modo, a concessão de lotes agrícolas nas proximidades de Bella Unión encontrava-se amplamente condicionada pela demanda industrial de matéria prima e esta última havia estagnado em 2015, quando a usina da ALUR atingiu seu limite de processamento fabril. Além disso, o monocultivo canavieiro exigia o emprego de mão-de-obra assalariada em diversas etapas do processo produtivo, o que obrigava os agricultores provenientes das bases da UTAA a assumirem a função de patrões e, portanto, a entrarem em flagrante contradição com o lema "nem exploradores nem explorados", que sintetizava o tipo de relação de trabalho preconizado pelo sindicato. Sob tais condições de acesso à terra, os dirigentes da UTAA

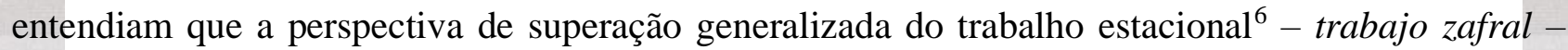
estava definitivamente postergada para as suas bases sociais. Esse não era um problema menor para eles, uma vez que sua organização havia lutado historicamente pela reforma agrária no Uruguai, sem deixar-se constranger pelos marcos jurídicos existentes ou pelas modalidades imperantes de posse e uso da terra. De fato, era desse passado que meus interlocutores pretendiam fazer eco em suas lutas atuais.

No primeiro tópico deste artigo, evidencio como o pensamento e a ação política cultivados pela militância da UTAA em 2015 eram dinamizados pela evocação de certas categorias originadas no âmbito de antigas lutas populares. Em seguida, exponho as premissas inerentes ao tipo de recordação praticado por meus interlocutores uruguaios, sugerindo que podemos defini-lo, nos termos de Walter Benjamin (2013), como “autênticas lembranças”. Argumento, ainda, que ao valorizarem

4 O INC administra a política agrária uruguaia, assegurando a distribuição da terra de acordo com os planos de desenvolvimento rural preconizados pelo governo.

${ }^{5}$ A usina da empresa ALUR, que pertencia a uma companhia fortemente endividada com os bancos públicos uruguaios, foi estatizada no ano de 2006 e, a partir de então, converteu-se no epicentro do complexo agroindustrial de Bella Unión, também conhecido como Complejo Sucro-Alcoholero. Desse momento em diante, o financiamento e o processamento da produção canavieira local passaram a ser responsabilidade da ALUR. Analiso e discuto os conflitos gerados pelas modalidades de gerenciamento e capitalização das unidades produtivas subordinadas à ALUR em Moraes, 2015, 2019 e 2021.

${ }^{6}$ A safra canavieira mobiliza cerca de 1.200 pessoas anualmente. Entre os meses de novembro e junho, concluída a colheita da cana-de-açúcar, tem início um período no qual a demanda de força de trabalho cai pela metade em Bella Unión. Conhecido como zafra seca, esse período é enfrentado pelas famílias de classe trabalhadora mediante várias iniciativas econômicas informais. A zafra seca era encarada pela UTAA como uma vicissitude imposta pelo corte manual da cana que poderia ser contrabalançada mediante a distribuição massiva de terras cultiváveis orientadas à produção familiar de alimentos. 
as lutas do passado em referência a "palavras-nome" emblemáticas, as "autênticas lembranças" proporcionam uma nova hipótese para empreender a releitura de certos acontecimentos pretéritos. Em linhas gerais, tal hipótese sugere que um acontecimento passado pode ser redescoberto à luz das inquietações atuais que o transformaram em objeto digno de atenção política. No terceiro tópico, a fim de colocar à prova essa hipótese, seleciono algumas palavras que mobilizavam a atenção dos meus interlocutores em 2015 para, em seguida, submergir-me nas formas de consciência que outrora elas sustentaram. O procedimento em questão abre caminho para uma análise sequencial da política. Os fundamentos metodológicos dessa análise radicam em uma antropologia das singularidades subjetivas (LAZARUS 1996) que nos convida a pensar as sequências políticas pretéritas no tempo de seu próprio desenvolvimento, ou seja, no período em que seu processo foi nomeado conscientemente através do uso singular e criativo da palavra. Finalizo o artigo refletindo sobre como as "autênticas lembranças" conectam uma autonomia política contemporânea com as autonomias políticas do passado e nos expõem ao que Benjamin denominaria uma "cristalização em mônada" do tempo da emancipação.

\section{PASSADO EM POLÍTICA}

Em junho de 2015, a UTAA experimentou uma notável inflexão política. Se até aquela data as reivindicações agrárias promovidas pela organização vinham ocorrendo em relativa simbiose com as políticas de desenvolvimento do governo nacional, então, dali em diante, os esforços do novo grupo de dirigentes que assumiu o comando do sindicato passariam a apontar noutro sentido. Ao propor uma política assente na separação radical entre "luta" e "gestão", as lideranças da UTAA empreenderiam o esforço de delinear um espaço de ação coletiva que não respondesse aos critérios de negociação política que vinham caracterizando a relação funcional - ainda que conflituosa - entre o movimento sindical dos cortadores de cana e as instituições públicas encarregadas da promoção do desenvolvimento econômico em Bella Unión. Isto implicou a abertura de uma sequência política na qual a luta pela terra, assim como a busca por melhores condições de vida para as bases do sindicato, estaria informada pela capacidade de planejamento dos próprios trabalhadores. No contexto de um diálogo que mantive em 2015 com os novos dirigentes da UTAA, Emilio, uma das figuras mais destacadas da militância canavieira, explicava-me o seguinte:

nós sabemos ver qual é a necessidade e [sabemos] apresentá-la. Fazemos isso através do movimento; movimento popular. [...] A burocracia é a gestão. A burocracia freia o desenvolvimento das condições de vida e dos interesses da população. A 
burocracia está a favor da parte que se opõe ao trabalhador. A gestão leva à burocracia e a medida de luta te leva à ação imediata. (EMÍLIO, Entrevista, 16-072015)

Sandro, companheiro de militância de Emilio e novo secretário geral da UTAA, acrescentava que, no concernente ao acesso à terra,

nós temos preocupações diferentes das deles [ou seja, do governo, encarnado na empresa ALUR]. Não queremos que existam exploradores nem explorados. O sistema proposto pela ALUR te encurrala, te endivida e te leva a explorar os outros [...] É preciso deixar uma questão bem clara: os velhos [dirigentes da UTAA] nos deram a ponta do fio e nós fomos caminhando, mas também fracassamos. Por isso eu digo que é necessário recolocar [a pergunta sobre] para que serve a terra. (SANDRO, Entrevista, 28-07-2015)

Por sua vez, Emilio entendia que a "luta pela terra" era uma expressão da "luta pela dignidade": "a luta pela terra significava que [...] tu pudesses te sustentar, ser dono do teu nariz". Nesse aspecto, ele estava em convergência com Isabel, outra dirigente do sindicato, para quem "terra é uma palavra que dignifica". Segundo ela, falar de "terra" implicava ter em mente que "somos dignos de ocupá-la, de possuí-la e de explorá-la [...] de forma cooperativa, buscando condições de trabalho adequadas". Reparemos que, para essas três lideranças, a palavra "terra" entrava numa constelação onde também apareciam as categorias "luta" e "dignidade". "Terra" descrevia não só o objeto da disputa fundiária, mas também seus propósitos e as condições nas quais a militância sindical estava autorizada a empreendê-la.

Ao mobilizar a palavra "terra", os novos dirigentes da UTAA reivindicavam para si uma disposição combativa que os confrontava com a possibilidade de lançar-se à ação imediata, isto é, a ocupação do solo de acordo com as condições de uso definidas no marco de seus próprios esforços organizativos. Havia, portanto, uma capacidade de ação disruptiva que meus interlocutores detectavam em si mesmos a partir do momento em que se pensavam como sujeitos potenciais de uma luta pela terra. Em poucas palavras, "terra" convocava e referendava uma mudança de atitude no tocante à busca de condições adequadas para viver o conforto material, a estabilidade laboral e a justiça social. Mas as coisas só eram assim porque "terra" pertencia a um passado político no qual os dirigentes da UTAA intuíam a existência de um tipo de disposição combativa cujos depositários, no tempo presente, seriam eles próprios. Nesse sentido, Emilio avaliava o seguinte: “tem um montão de história atrás de mim. Tu sonhas com o espírito de luta, com essas histórias que escutavas de pessoas que saíam para pelejar [...] Se tu fores ver, tudo começa aqui no norte [do Uruguai]. A revolução do 
Uruguai começou aqui, de mãos dadas com a UTAA". "A questão - prosseguia Emilio - é que nós, às vezes, não nos damos conta do que temos aqui porque vivemos isso cotidianamente".

Detenhamo-nos sobre o caráter à primeira vista paradoxal desta reflexão: "não nos damos conta [de que a revolução começou aqui] porque vivemos isso cotidianamente". Emilio ajudava a esclarecer o paradoxo: "tu podes ter uma visão diferente de uma mesma coisa que está acontecendo porque tu olhas essa coisa de outro ângulo". Ainda que as pessoas compartilhem o conhecimento de certos fatos, o ponto de partida para fazer algo diferente com as suas vidas não reside nessa vivência contemplativa do evidente, mas sim no olhar, ou seja, no "ângulo" a partir do qual determinada "coisa" é abordada. Assim, sonhar com o velho "espírito de luta", com "essas histórias" contadas por companheiros e parentes, significava algo mais do que visualizar fatos dados, que marcaram a vida de alguns com o brilho da vitória ou as sombras da derrota. Tratava-se, com efeito, de reagir às evidências do acontecido a partir do próprio presente, introduzindo nele a possibilidade de uma escolha existencial. Se, por acaso, fôssemos capazes de "dizer sim, os direitos são meus, eu quero mudar de vida, mudar a vida dos meus filhos e não só a minha vida" e reconhecer que "a UTAA é mobilização", então "até nossa conduta muda e velhos slogans começam a viver". Emilio avaliava que "o ser humano, quando pode estar bem, ele aproveita, mas se tiver que estar numa situação extrema, também sobrevive, com menos do que nada". A capacidade de ação individual e coletiva não seria uma consequência imediata das circunstâncias dadas, mas sim o efeito da adoção de um “ângulo" de visão que nega o presente e revela a inadequação dos vivos diante da realidade que eles mesmos experimentam. A lembrança das velhas lutas e de seus slogans era o meio para operar uma espécie de des-identificação em relação ao presente, graças a um desvio de perspectiva - ou mudança de ângulo - que correlacionava os atuais militantes do sindicato com a decisão de "mudar de vida" professada por tantos outros em tempos idos.

Sempre que meus interlocutores se propunham a problematizar sua posição a respeito da luta fundiária tomando por referência a categoria "terra", esta última invocava, de maneira implícita, a figura de Raúl Sendic, um dos fundadores da UTAA e o mais célebre líder do Movimiento de Liberación Nacional - Tupamaros (MLN-T) 7 . "Sendic" e "terra" se referenciam mutuamente. Evocar o segundo termo implicava pressupor o primeiro. O nome de Sendic estava subentendido na já citada

\footnotetext{
7 Raúl Sendic Antonaccio foi um dos fundadores da UTAA, em 1961. Mais tarde, ele organizaria a guerrilha do Movimiento de Liberación Nacional - Tupamaros em cooperação com outros militantes revolucionários que se tornaram quadros importantes da esquerda uruguaia, como José "Pepe" Mujica, Eleuterio Fernández Huidobro e Jorge Zabalza. No terceiro tópico, terei a oportunidade de narrar com maior detalhe as implicações políticas da influência de Sendic na UTAA durante os anos 1960.
} 
alusão de Sandro aos "velhos" dirigentes do sindicato. E quando Emílio sugeria que "a luta pela terra significava...", o verbo significar, conjugado no pretérito imperfeito, remetia ao tempo de Sendic. Já na fala de Isabel, a terra emergia como um objeto passível de "ocupação" porque tal possibilidade fora afiançada pela política revolucionária fomentada por Sendic no extremo norte do Uruguai em meados dos anos 1960. Em suma, era sob o signo espectral de Sendic que "terra" se tornava um emblema de combate e, por isso mesmo, passava a descrever menos o objeto de uma demanda do que a irreverência política almejada pelos próprios demandantes.

Lembro-me de que, no primeiro encontro com os dirigentes da UTAA empossados em 2015, perguntei a eles sobre seus planos para o futuro. Foi então que Emilio apontou para um dos muitos retratos de Sendic espalhados pelas paredes da sede sindical e disse que essas fotos estavam ali "para recordar-nos de qual é a luta da UTAA". Em seguida, falou-me de "autonomia" e explicou que exercêla significava não só defender os interesses de quem era formalmente representado pelo sindicato, mas também "os interesses de todo o povo". Conectar-se com a "luta da UTAA" exigia uma disposição para conceber e defender certas aspirações coletivas que extrapolavam a negociação sindical entre patrões e trabalhadores. "Autonomia" era, precisamente, o que singularizava as lutas populares do passado, ao mesmo tempo em que constituía um procedimento elementar para voltar a "sentir" aquilo que meu interlocutor chamava de "a força da UTAA". Como argumentei com detalhe em outra oportunidade (MORAES, 2019), “autonomia” designava, de modo simultâneo, um possível e um passado. Prospectivamente, essa palavra indicava a existência de uma capacidade - ou "força" - disruptiva suscetível de ser novamente exercida a qualquer momento. Retrospectivamente, o passado apresentava-se como o lugar de ocorrência de determinada "autonomia" cujo rastro inequívoco seria, nem mais nem menos, a persistência de certas palavras e nomes - "terra", "Sendic" - que não pareciam dizer respeito ao mundo das reivindicações sindicais cotidianas. Na persistência instigante dessas palavras e nomes tornava-se lícito, para os meus interlocutores, decifrar a existência passada de uma forma de organização autônoma cujo reconhecimento os defrontava com uma possível autonomia vindoura. Quero sugerir que, de algum modo, o ato de conceber a evidência fragmentária do já ocorrido como o índice ${ }^{8}$ de uma "força" atualizável significava descobrir o sentido

${ }^{8}$ A noção de "índice" e, precisamente, a de "índice histórico" foi recuperada por Ana Ramos $(2011$; 2016) do pensamento de Walter Benjamin. Para a autora, os índices são suportes fragmentários da lembrança que "nem sempre se articulam em narrativas ou tramas, ou nem sempre adquirem sentidos políticos e vivenciais para as pessoas" (RAMOS 2011, p. 144), razão pela qual os deveríamos pensar como "chaves potenciais de interpretação" (Ibidem). Seguindo uma linha de argumentação semelhante, Eduardo Kohn (2002, p. 563) fala de "poderosas imagens não discursivas" que podem ser "convincentes sem serem totalmente entendidas". Tais imagens doam-se a sucessivos atos de bricolagem, interpretação e fabulação que jamais anulam sua conexão básica com algo que, por ter "ocorrido realmente", não se esgota no processo 
de antigos esforços coletivos não no contexto em que eles ocorreram, mas, ao contrário, em sua errância trans-temporal sob a forma de palavras soltas que, incrustadas nas paisagens do presente, sussurravam a quem as soubesse ler a latência de uma força transformadora à espera de ser resuscitada.

\subsection{Premissas da autêntica lembrança}

Walter Benjamin (2013, p. 99) definiu as "autênticas lembranças" como a manifestação repentina do sentido nos quadros de uma intelecção presente que retém os registros da ação humana passada sem a intenção de contar sua história. Dessa maneira, os objetos da lembrança, "arrancados de todos os seus contextos anteriores", tornam-se "objetos de valor nos aposentos sóbrios de nossa compreensão tardia" e fontes para a "composição de uma imagem de quem recorda" (Ibidem). Para as pessoas que se envolvem num processo atual de mobilização coletiva em cujo âmbito o passado faz algum sentido, o que está em jogo é a postulação de paralelismos temporais sincrônicos: um momento se detém ao lado de outro momento numa relação de determinação recíproca, sem a mediação das cronologias. O caráter duplamente revelador desse paralelismo reside em que, ao revalorizar o passado apesar das sucessões cronológicas conhecidas, ele também prenuncia a irreverente singularidade da práxis presente na qual ocorre. Os paralelismos sincrônicos postulam, portanto, um instante de passado do qual algumas pessoas decidem tornar-se o presente imediato. Nos termos de Emilio, por exemplo, bastaria dizer "sim" à figura do passado herdada pelo relato dos velhos ou preservada nas paredes do sindicato para estar sob sua influência direta. Nesse registro, os rastros do passado evidenciam que algo simplesmente aconteceu: um gesto antigo - ou nem tanto passa a ser percebido em sua originalidade radical sob a luz de uma nova experiência autêntica, verdadeiramente política (BENJAMIN, 1989, p. 182), que se manifesta na decisão de dizer "sim” a um chamado interpelador. Tal experiência faz "uma determinada época saltar do curso da história [...], uma determinada vida [saltar] da época e uma determinada obra [saltar] da obra geral" (BENJAMIN, 2001, p. 51). Sem ser independente de um processo de produção específico - e, talvez, exatamente por isso -, aquilo que "salta" de seu contexto descobre-se como potencialmente autônomo em relação à posterior captura no continuum da história. Dita autonomia é verificada, uma e outra

de sua representação. Segundo Kohn, “o que realmente ocorreu é uma fonte constante de inspiração potencial, alojada [...] em imagens poderosas, frequentemente enigmáticas, que às vezes permanecem inativas” (Ibidem). 
vez, pelas "lembranças autênticas"9. Trata-se de um tipo de exercício intelectual que capta as marcas de apostas coletivas pretéritas como se fossem registros de intensidades singulares, portadoras de um nome, mas despojadas de qualquer filiação exaustiva ao contexto histórico no qual tiveram lugar. Daí que elas possam voltar a ser efetivas em qualquer tempo. Em poucas palavras, na "autêntica lembrança" o importante é a marca deixada pela ação política pretérita e a forma como ela nos sensibiliza, aqui e agora.

As lembranças que estimulavam a militância da UTAA em 2015 sugerem que, de vez em quando, o passado também pode existir liberto de todo contexto e de toda história: errante, extemporâneo, perturbador. A “autêntica lembrança” possui uma autonomia de registro que também incide sobre aqueles rastros de passado retidos nas tramas de seu peculiar processo intelectivo. Foi Louis Althusser quem indicou que a política só encontra suas condições de possibilidade ali onde as constitui e reproduz (SIBERTIN-BLANC, 2011). Nesse caso, se uma política que se pretende autonômica perscruta no passado suas próprias condições de possibilidade, então poderíamos dizer que tal prospecção ocorrerá no futuro perfeito - isto é, no registro do que terá sido -, o que significa prescrever ao que já aconteceu as mesmas condições arrogadas pelo ato de autonomização que, hoje, o reivindica e recorda. Em síntese, as apostas políticas pretéritas terão sido autonomias sempre e quando assim o declarar um novo esforço autonômico no tempo presente.

Prolongar os efeitos intelectivos da "autêntica lembrança" no terreno do estudo das políticas passadas é o gesto que pretendo imitar no terceiro tópico. Tal procedimento não consiste - e não poderia consistir - em um exercício historiográfico, mas sim na revisão de fontes primárias e secundárias em busca de palavras muito precisas; palavras que, ao resplandecerem sob a luz da "autêntica lembrança" experimentada em 2015 pelos dirigentes da UTAA, convidam-nos a lê-las no registro da "autonomia" que elas eventualmente sinalizam. Antes de colocar a prova esse procedimento analítico, cabe oferecer algumas especificações de ordem teórico-metodológica.

\footnotetext{
9 Adjetivar certas lembranças como "autênticas" não supõe, necessariamente, que existam lembranças "falsas". Uma lembrança é autêntica quando o único contexto possível de seu objeto - ou seja, do que é recordado - é o ato que o engendrou. Nesse caso, os rastros da ação humana pretérita possuem valor porque foram efetivamente deixados por alguém em certa circunstância. "Terra" e "Sendic" são lembranças valiosas na medida em que retêm a marca de um gesto original, de um esforço inventivo único, isto é, de uma autonomia. O contrário da lembrança autêntica seria a narrativa cronológica e historicista, na qual o sentido de um evento é indissociável de uma contextualização em termos de causas e consequências. Assim, por exemplo, no registro historiográfico - que é um registro cronológico - "terra" e "Sendic" não significam grande coisa em si mesmos. O importante seria lê-los no curso de um processo que os transcende e que diz respeito, por exemplo, à história da nação ou à história das classes trabalhadoras e de sua interação com o Estado. As palavras não introduzem sua própria historicidade, mas convocam à reconstrução da historicidade que as abrange. É o contexto histórico abrangente que esclarece os usos da palavra e a ação dos sujeitos. Para uma crítica das práticas historicistas de contextualização, ver Michael Taussig (1995).
} 


\section{PENSAR POLITICAMENTE AS POLÍTICAS PASSADAS}

Evocar o conteúdo autonômico de um acontecimento pretérito no seio de uma mobilização política vigente tem consequências diferentes daquelas produzidas por um gesto análogo que se leva a cabo fora de qualquer luta coletiva. Para os dirigentes da UTAA, a suposição da existência de uma "força" autonômica passada os deveria conduzir à enunciação das condições necessárias para o relançamento da autonomia. Assim, o reconhecimento de uma velha autonomia defrontava esses sujeitos com a possibilidade de exercer sua própria autonomia. Por outro lado, para mim, enquanto pesquisador, a suposição de uma autonomia passada não desencadeia um esforço político imediato, mas desdobra-se num procedimento de identificação das condições subjetivas de possibilidade subjacentes a essa eventual autonomia. Dado que me interessa revisitar os conteúdos de certos processos de subjetivação política, estou operando no terreno de um pensamento das singularidades subjetivas. Sistematizado pelo antropólogo Sylvain Lazarus (1996; 2001; 2013), esse pensamento converge com as condições de recordação/lembrança praticadas por meus interlocutores da UTAA em um aspecto essencial: nele, a palavra indica a ocorrência potencial de algo extraordinário. A persistência de certas palavras - e não de outras - sinalizaria o ponto de apoio a partir do qual certo processo de subjetivação conseguiu nomear uma determinada possibilidade coletiva. É necessário partir da palavra se quisermos acessar a potencial autonomia ensaiada por aqueles que alguma vez a enunciaram. Quando se converte no índice emblemático de um esforço específico de problematização da realidade, poderíamos dizer que a palavra devém nome: "palavra-nome”. É em função desse tipo de palavra que toda uma redisposição das funções e dos atributos sociais poderá ser pensada.

A título de exemplo, seria correto dizer que, em 2015, "UTAA" era a palavra crucial da política professada por meus interlocutores. A invocação dos índices de velhas lutas populares, como "terra" e "Sendic", servia à problematização de qual era o tipo de "força" que "UTAA" deveria denotar. Em constelação com "terra" e "Sendic", "UTAA" era algo mais do que a razão social de um sindicato: também nomeava uma aposta política que, através da separação radical entre "gestão" e "luta", propunha a subtração da prática militante às regras convencionadas para a tramitação de certas demandas coletivas. No entanto, houve um tempo em que "terra" foi o nome emblemático de uma sequência política singular. Se agora posso fazer essa afirmação é porque, graças à irrupção de "terra" 
no espaço intelectual da política popular que conheci em 2015, tive a chance de verificar a emergência histórica desse nome e de indagar pela possível autonomia subjacente a ele. Como veremos no próximo tópico, foi em relação à palavra "terra" que, ao longo da década de 1960, algumas pessoas decidiram construir um espaço de problematização política no qual esteve em jogo a possibilidade de suspensão do regime de assalariamento e o compromisso coletivo com a revolução social. Essas pessoas pertenciam à recém fundada UTAA, mas a singularidade de sua ação militante atrelava-se à insígnia "terra". Isso ocorreu precisamente entre 1964 e 1971, período em que a própria bandeira do sindicato cedeu lugar a um estandarte com três faixas paralelas - a superior e a inferior em cor azul e a do centro branca - atravessadas, em diagonal, por uma tira vermelha que trazia estampada, com letras maiúsculas, a palavra "TERRA”. Mas não nos adiantemos. Antes de elucidar os conteúdos do processo autonômico que encontrou na palavra "terra" sua marca perene e distintiva, quero explicitar o protocolo de análise que informará minha abordagem.

O pensamento das singularidades subjetivas encara a política como um momento de autonomia - e não como um campo ou dimensão permanente da vida social. Ao assumir essa premissa, uma antropologia das singularidades subjetivas se coloca a tarefa de pensar o que se pensa no interior de um pensamento da política, o que supõe acompanhar a articulação de suas categorias e identificar suas prescrições imanentes. Mais adiante, retornarei sobre a noção de "prescrição". Por ora, é importante sublinhar que tal antropologia prescinde da necessidade de submeter o que as pessoas dizem e fazem a qualquer sistema de regras implícitas que pudesse constituir um background objetivo para a explicação das mutações subjetivas (NEOCOSMOS 2012a; HAYEM 2012). Ao fim e ao cabo, o axioma fundamental da antropologia das singularidades subjetivas é o mesmo que assegura a possibilidade de qualquer autonomia política. Sintetizemo-lo assim: o que as pessoas podem pensar ou fazer não é, necessariamente, fruto das regras e das estruturas, mesmo quando ocorra em meio a elas ${ }^{10}$. Lazarus chamou seu programa teórico de "antropologia do nome" para enfatizar que, nele, o importante é detectar o estabelecimento de alguma singularidade. Nome é aquilo que denota sem significar; é o que sinaliza uma existência e permite acompanhá-la em seu devir singular. “Terra" é um nome, assim como "Sendic". Em breve, teremos a oportunidade de saber o que essas palavras ajudaram a nomear. Por enquanto, é necessário dizer que a antropologia das singularidades subjetivas pretende orbitar as categorias do pensamento das pessoas sem fazê-las depender de

${ }^{10}$ Aqui, provavelmente estejamos bem longe do cânone da antropologia política "clássica", mas isso não nos aproxima de certas expressões contemporâneas da "antropologia da política". Em outro trabalho (MORAES, 2020) dediquei-me a mesurar as distâncias entre a antropologia de Lazarus e algumas das variações mais visíveis do estudo antropológico contemporâneo da política. 
modelos explicativos de segunda ordem, pertencentes a outros processos intelectivos. Trata-se, por conseguinte, de um programa reflexivo orientado a pensar o pensamento das pessoas fora do substrato dos grupos e em ausência de toda circunscrição disciplinar de objeto ${ }^{11}$. Com efeito, aqueles/aquelas que pensam - isto é, "as pessoas" - serão tomados/as como "indistintos determinados" - ou seja, não sabemos a priori o que são - que subjetivam sua própria situação e a colocam em jogo, o que implica colocar-se em jogo a si mesmos/as e, eventualmente, tomar decisões a respeito, compartilhá-las e submetê-las à prova. Lazarus se expressa nos seguintes termos:

[a questão] não é quem pensa, nem uma problemática do sujeito nem uma problemática das classes [...] as pessoas são um indistinto determinado [indistinct certain] que pode ser isolado pela evolução da pesquisa antropológica. $\mathrm{O}$ indistinto determinado não designa nem um grupo nem uma estrutura nem um modelo. Podese dizer que é um ser-aí indistinto com relação à história e à sociedade. No cara a cara entre as pessoas e seu pensamento não se trata de reinstalar a confrontação entre representações e fatores objetivos concernentes às pessoas (profissão, salário, formação, lugar de moradia, etc.), mas sim de indagar, no pensamento das pessoas, sobre a relação das pessoas com seu pensamento (LAZARUS, 1996, p. 53). (grifos originais)

Quando as pessoas “caem” sob o processo intelectivo de um pensamento, ou seja, quando elas se pensam deliberadamente no registro das categorias singulares de um pensamento, podemos dizer que há relação entre "as pessoas" e seu pensamento. A (auto)inclusão das pessoas no registro de determinado pensamento ocorre quando elas reagem a uma prescrição e decidem não apenas problematizá-la, mas também colocá-la em prática. O período e a forma de existência da ação prescritiva - isto é, da ação condicionada por uma prescrição - denomina-se "sequência política". Enquanto perdurar a relação entre as pessoas e um pensamento, a sequência política estará em pleno desenvolvimento. E quando, por alguma razão, essa relação se interromper, a sequência política terá chegado ao seu término. Finalizada a sequência, o que resta é o seu pensamento: o enunciado de seu campo de possíveis. Ali, poderemos identificar as cristalizações prescritivas da sequência terminada. Por cristalizações prescritivas, devemos entender aquilo que uma sequência anunciou como possível em oposição ao previamente dado.

\footnotetext{
11 Para colocar um exemplo trivial: não seria conveniente fazer com que um enunciado qualquer passe a depender da "cultura" na qual ele supostamente ocorre. Poderíamos substituir "cultura" por qualquer objeto invisível cuja mobilização sob a forma de conceito tenda a tipologizar um pensamento ao convertê-lo no "caso" de algo, ou seja, na expressão local de uma objetividade suposta que transcende o próprio pensamento, o engloba e o explica. Na antropologia de Lazarus, a única existência prévia ao pensamento - uma existência dada, que não está por ser constituída - é o "real”, mas esse real é inominável e só pode ser acessado a partir de suas problematizações singulares, expressas em categorias de pensamento. Daí que, para Lazarus, o pensamento seja, essencialmente, uma relação singular do real.
} 
A singularidade sequencial de uma política é acessível, em suma, através das categorias que foram subjetivadas e problematizadas por um conjunto específico de pessoas durante certo tempo e em determinados lugares tendo em vista a prescrição de um possível. O que significa "prescrever um possível'? Para Peter Hallward (2005), cuja matriz teórica converge amplamente com a de Lazarus, a prescrição transforma o cotidiano em seu oposto, pois converte relações sociais que a princípio eram inconsequenciais, ambivalentes ou multipolares em relações consequenciais, isto é, bipolares e divisórias. Ao fazer isso, a prescrição antecipa seu poder subsequente, posto que defronta os sujeitos políticos com um possível que eles deverão sustentar materialmente, em seus corpos e ações. No processo de enunciar uma prescrição, o sujeito político define suas fronteiras:

O sujeito político prescritivo existe em sua interface militante e emergente com o mundo e não tanto em alguma localização psicológica (e muito menos cultural ou biológica). Em outras palavras, a autonomia prescritiva presume necessariamente algum tipo de salto qualitativo na constituição do sujeito, um salto que habilita sua liberdade relativa diante das determinações causais ou pré-subjetivas (HALLWARD 2005, p. 781).

O breve estudo desenvolvido no próximo tópico identifica as prescrições de uma sequência política cuja existência, marcada pelos nomes "terra" e "Sendic", foi sinalizada pela "autêntica lembrança" dos militantes sindicais que conheci em 2015. Conto com as seguintes fontes para identificar o conteúdo prescritivo da sequência em questão: as memórias publicadas de Ruben Santana Pérez, um cortador de cana-de-açúcar que participou das lutas agrárias da UTAA nas décadas de 1960 e 1970; a transcrição de alguns trechos do boletim Tierra y Libertad, publicado pelo sindicado no início dos anos 70; uma entrevista concedida pelos dirigentes da UTAA ao jornal Cuestión, em 1971, e todas as edições do semanário Marcha ${ }^{12}$ que registraram o desenrolar da política popular nos canaviais do norte uruguaio desde 1964 até 1972. O conteúdo desses documentos foi complementado com fontes historiográficas que permitiram delinear as situações de sociabilidade em meio às quais surgiram aquelas prescrições que serão identificadas nas próximas páginas.

\section{IDENTIFICAÇÃO DA SEQUÊNCIA AGRÁRIA (1964-1972)}

\footnotetext{
${ }^{12}$ Fundado e dirigido por Carlos Quijano, Marcha foi um semanário político e cultural uruguaio publicado entre 1939 e 1974. Destacou-se tanto por sua linha independente quanto por sua equipe de colaboradores, que incluía Mario Benedetti, Eduardo Galeano e Alfredo Zitarrosa. Consultei uma coleção completa desse periódico no repositório virtual Anáforas, mantido pela Facultad de Información y Comunicación da Universidad de la República. Para o estudo apresentado neste artigo, utilizei, principalmente, aquelas notas jornalísticas que se propunham a recuperar a fala dos militantes da UTAA mediante entrevistas ou que ofereciam transcrições de documentos - comunicados, cartas - emitidos pelo sindicato e por seus correligionários.
} 
A fundação da UTAA, em 1961, foi o resultado da aliança bem-sucedida entre um núcleo de trabalhadores açucareiros desejosos de melhores condições de trabalho e um militante do Partido Socialista chamado Raúl Sendic Antonaccio, que, à época, percorria o interior uruguaio fomentando processos de sindicalização rural ${ }^{13}$. Ao longo de seu primeiro ano de existência, o novo sindicato dos cortadores de cana de Bella Unión promoveu uma importante greve salarial que foi inicialmente repudiada pelos patrões e reprimida pelo Exército. Em tais circunstâncias, a UTAA intensificaria suas táticas de luta: estruturas industriais seriam ocupadas e os funcionários administrativos dos engenhos locais sofreriam coação física até que as demandas do sindicato fossem atendidas. A postura adotada pela UTAA redundou em demissões massivas e na disseminação do desemprego entre os trabalhadores sindicalizados. No início de 1962, já circulavam "listas negras" em todas as plantações de Bella Unión. Nas palavras de Ruben Santana Perez, que atuara ativamente nas filas da organização, a "UTAA passou a ser um sindicato de desempregados" (SANTANA PEREZ 2013, p. 65). Nessa conjuntura, os desafios da militância sindical deixaram de responder, necessária e unicamente, à defesa dos direitos trabalhistas. Aos poucos, começaria a delinear-se uma sequência política fortemente marcada pela reivindicação fundiária. Daí minha decisão de denominá-la "sequência agrária".

Caracterizada pela reivindicação e pelo uso da violência política, a sequência agrária assentou aquelas palavras que, em 2015, funcionariam como metáforas da possibilidade de conduzir a ação coletiva por fora das instâncias de negociação legitimadas pela normativa vigente. O lugar privilegiado para o desenvolvimento da sequência agrária foram as quatro "Marchas por la Tierra" realizadas pela UTAA entre 1964 e 1971. Essas marchas viabilizaram a articulação das seguintes prescrições: 1) o peludo ${ }^{14}$ é um camponês; 2) a terra pode ser tomada. "Sendic", "luta", "camponês" e "terra" constituíram categorias relevantes da sequência em questão. Nela, "peludo" foi pensado em sua relação potencial - e problemática - com a categoria "camponês", ao passo que as categorias "Sendic", "luta" e "terra" subsidiaram dito esforço de pensamento. Veremos que graças à incorporação do slogan "por la tierra y con Sendic", o trabalhador canavieiro ("peludo")

\footnotetext{
${ }^{13}$ No concernente ao surgimento das lutas agrária e sindical no norte uruguaio, cabe mencionar o trabalho de Yamandú González (1994) e o engajado relato de Mauricio Rosencof (1989).

14 "Peludo" é uma das formas como autodenominam e são denominados os cortadores de cana-de-açúcar de Bella Unión. O vocábulo faz uma analogia entre o animal conhecido como tatu-peludo (Euphractus sexcinctus) e o aspecto dos cortadores durante o processo de trabalho, encurvados sobre as plantas de cana, com o corpo tingido, dos pés à cabeça, pela fuligem do canavial queimado.
} 
estigmatizado pelas listas negras virá a enunciar-se como o beneficiário e o protagonista potencial de um tipo muito especial de "reforma agrária".

Em meados de 1962, Raúl Sendic começou a discutir com alguns dirigentes da UTAA sobre a possibilidade de exigir do Instituto Nacional de Colonización (INC) a expropriação dos latifúndios de Silva y Rosas e Palmas de Miranda. Ambas as propriedades, situadas em Bella Unión, totalizavam uma extensão de cerca de 30.000 hectares improdutivos. Segundo Samuel Blixen, que procurou reconstruir as confabulações de 1962, a solicitação de expropriação de ambos os latifúndios seria simultânea à sua ocupação pelos militantes da UTAA: "a ideia era arar a terra o antes possível e plantar [...] de modo que a expropriação ocorresse pelas vias de fato" (BLIXEN, 2000, p. 72). Esse plano nunca chegou a se concretizar, dada a dificuldade de aglutinar em torno dele o apoio da esquerda montevideana, cujas preocupações, naquele momento, estavam mais concentradas nas eleições presidenciais do mês de novembro. No entanto, a intenção de distribuir terras "pelas vias de fato", através da ação direta dos próprios assalariados rurais, seria retida no horizonte político da longa sequência de mobilização coletiva que começou em 1964.

Em março de 1963, depois de participar da primeira operação militar do MLN-T, destinada a expropriar armas num clube de tiro do interior do país, Raúl Sendic passou para a clandestinidade e começou a ser procurado pelas forças de segurança uruguaias. As atividades organizativas da UTAA prosseguiram, em Bella Unión, sob intenso controle da polícia. Nessa época, alguns dos dirigentes do sindicato começaram a exercer uma dupla militância, atuando simultaneamente em tarefas organizativas legais e em pequenas operações clandestinas, associadas, geralmente, à transmissão de mensagens entre os dirigentes do MLN-T. Em janeiro de 1964, cortadores de cana e operários fabris organizados pelo sindicato ocuparam as instalações de uma das usinas de Bella Unión para exigir o pagamento do décimo terceiro salário e de outras remunerações atrasadas. Houve dura repressão militar e a plataforma reivindicativa do movimento foi atendida de maneira muito parcial. Algumas semanas antes, centenas de cortadores de cana de um engenho vizinho, situado na localidade de El Espinillar, haviam ficado sem trabalho. Começava a zafra seca, período no qual a demanda por mãode-obra nos canaviais do norte uruguaio se reduz de maneira dramática. A pauperização imposta pelo fim da safra era acentuada pela perseguição sindical generalizada, que impedia de forma permanente o acesso de quase uma centena de trabalhadores combativos às fontes de trabalho disponíveis na zona (BLIXEN, 2000). Nesse contexto, a UTAA deliberou pela realização de uma marcha a Montevidéu sob o slogan "Tierra para quien la trabaja”. Em suas memórias, Ruben Santana (2013, p. 72) afirma 
que "a aspiração principal [da marcha de 1964] era sensibilizar as autoridades e a opinião pública", razão pela qual os interlocutores prioritários do movimento seriam o INC e o Poder Legislativo.

Em 21 de fevereiro de 1964, cerca de duzentos trabalhadores rurais partiram com suas famílias rumo a Montevidéu para exigir do parlamento a expropriação imediata de 30.000 hectares improdutivos. Poucas semanas depois, nas páginas do semanário Marcha, Eduardo Galeano relatava algo que chamou sua atenção quando foi receber os “cañeros [canavieiros]" recém-chegados à capital do país: "há um rosto sobre todos os rostos que avança diante da marcha e que está pregado nas paredes de terra, palha e cana dos barracos: o nome e a cara de Raúl Sendic" (MARCHA, 13-3-1964, p. 11). Em suas memórias, Ruben Santana complementa esta descrição: "nosso estandarte era um enorme quadro com a imagem de Raúl e um slogan que virou lenda: 'pela terra e com Sendic; expropriação dos trinta mil hectares de Silva y Rosas" (SANTANA PEREZ, 2013, p. 72). Ao mesmo tempo em que interpelavam os poderes do Estado através da demanda de expropriação fundiária, os peludos também declaravam fidelidade à figura de seu líder, Raúl Sendic, cujos métodos de ação política confrontavam diretamente os marcos jurídicos e institucionais estabelecidos. A reivindicação do nome de Sendic expressava uma capacidade de ação que os próprios militantes da UTAA estavam dispostos não só a defender e atualizar, mas também a apresentar como possibilidade para o movimento popular uruguaio de meados dos anos sessenta.

No ato de primeiro $1^{\circ}$ de maio de 1964 , realizado com a presença dos peludos em Montevidéu, Colacho Estevez, que substituíra Sendic em algumas tarefas organizativas do sindicato, proclamava que "estamos dispostos a combater a burguesia no terreno que ela escolher. Se nos derem pauladas, devolveremos pauladas; se nos derem balas, devolveremos balas" (Apud BLIXEN, 2000, p. 97). Essa "disposição" seria colocada à prova num grande confronto com a polícia diante da sede do Poder Legislativo uruguaio no dia 7 de maio, quando os peludos pressionavam os legisladores pela discussão de seu projeto de expropriação fundiária. Durante o altercado, que Ruben Santana define como uma "batalha", María Silva, uma adolescente de 15 anos de idade, integrante da marcha, foi alvejada na perna por um disparo efetuado pela polícia. Em junho, pouco antes de os militantes da UTAA retornarem a Bella Unión, três peludos, todos eles dirigentes do sindicato, terminaram presos depois de trocarem tiros com a polícia durante uma tentativa de assalto a banco. Quase cinquenta anos depois desses eventos, María Silva, a jovem ferida pela polícia em 1964, recordaria a adesão da UTAA à ação direta e a identificação de seus militantes com o MLN-T como o início de uma nova etapa política em relação a qual ela nutria profundas reticências: o sindicato que começou a emergir entre a metade e o final da década de 1960 estava deixando de ser a "sua UTAA", que fora organizada 
pelo "Sendic sindicalista", para atravessar, sob o signo do "Sendic tupamaro", profundas redefinições táticas e programáticas (MERENSON, 2016, p. 117) ${ }^{15}$.

Em meados de 1964, novas lideranças passaram a integrar a diretoria da UTAA. Em 1965, durante a segunda Marcha por la Tierra, numa entrevista concedida pelos dirigentes da organização aos jornalistas Héctor Rodríguez e Pepe Quijano, esboçava-se uma reflexão sobre a dificuldade de negociar o corolário político das lutas agrária e sindical por meio do "parlamento". Segundo os peludos, "tanto as reivindicações trabalhistas como a demanda de terras" teriam deixado de ser objeto de interesse para os deputados "quando terminou a agitação provocada pela presença dos manifestantes [em Montevidéu durante a marcha de 1964]”. Por essa razão, concluíam, "esta será a última marcha. Se tivermos sucesso já não precisaremos marchar de novo; mas se fracassarmos, teremos de adotar outros métodos de luta" (MARCHA, 23-4-1965, p. 8).

Pouco a pouco, a luta pela terra começou a ser problematizada em relação à palavra "revolução", como fica evidente nesta passagem de uma carta anônima, assinada por "Um integrante da marcha canavieira" e publicada em Montevidéu no mês de abril de 1965: "conquistar a terra não é sinônimo de revolução; mas é inegável que constitui a primeira tentativa séria de se encaminhar em direção a ela". A carta prossegue: "por isso, dizemos que se abre uma etapa definitiva: ou se está com os canavieiros de forma militante ou se está contra eles. Se está objetivamente contra eles inclusive quando se os pretende apoiar com uma que outra declaraçãozinha que não serve para nada" (MARCHA, 9-4-1965, p. 8) ${ }^{16}$. A "luta" dos peludos, ancorada em sucessivas peregrinações a Montevidéu, adquiria, paulatinamente, o aspecto de um processo de conversão revolucionária que precisava ser ratificado não só com demonstrações retóricas de fé e fidelidade, mas também com a disposição de se expor efetivamente às provações do combate político violento, travado em meio à crescente repressão policial e militar. Na terceira Marcha por la Tierra, em 1968, um padre da cidade de Treinta y Tres respondeu ao chamado da UTAA e decidiu acolher os peludos na casa paroquial. Diante das reações iracundas da comunidade católica local, ele revelou à imprensa seu desejo de conversão, festejado pelo sindicato: "se o Bispo me desaprovar [...] renunciarei ao meu cargo e me unirei à marcha dos canavieiros" (MARCHA, 18-4-1968, p. 11).

15 Em seu denso trabalho sobre o devir histórico da política popular nos canaviais de Bella Unión, Silvina Merenson (2016) relata as derivas da UTAA entre a luta sindical e a aposta revolucionária, recuperando as memórias desse processo, bem como as esperanças, temores e conflitos daqueles e daquelas que o viveram em carne própria.

${ }^{16}$ A analogia é irresistível: "aquele que não está comigo é contra mim, e aquele que comigo não ajunta, espalha" (LUCAS $11: 23)$. 
Em seu longo périplo pelo interior do país, sob assédio inclemente do aparelho repressivo, expostos às privações da vida nos acampamentos, os peludos também tiveram que enfrentar a morte de uma de suas companheiras de luta: próximo da cidade de Treinta y Tres, durante a Tercera Marcha por la Tierra, Lourdes Pintos sucumbiu ao tétano, deixando três filhos órfãos. Apesar das dificuldades e sofrimentos gritantes, um manifesto distribuído pela UTAA esclareceu que a adesão à luta do sindicato não deveria ser fruto da comoção gerada pela pobreza de quem marchava, mas sim do convencimento perante a "verdade" da qual os manifestantes eram portadores:

não viemos comover com nossa pobreza; nós, os peludos, temos como arma de convencimento a força de nossas ideias e de nossa luta [...] sabemos que a luta é dura porque é contra os ricos, porque dizemos aos irmãos de classe a verdade, lhes dizemos que nosso futuro é de terra ou morte (MARCHA, 18-4-1968, p 11).

Compartilhada entre "irmãos", a "verdade" dos peludos não precisava da mediação do Estado para se tornar eficaz e valer para todos. Tal verdade obtinha na luta seu efeito vinculante. De fato, por volta de 1968, o público-alvo das reivindicações agrárias da UTAA já não era nem o "parlamento" nem "os políticos", segundo esclareceu um dos dirigentes do sindicato quando a terceira Marcha chegava à capital do país: "viemos falar diretamente com os operários, nas fábricas; viemos fazer mesas redondas e discutir nas ruas. Queremos criar consciência a favor de uma reforma agrária que não só nos dê os 30.000 hectares do latifúndio Silva y Rosas, mas também terra para todos os que precisarem trabalhar” (MARCHA, 26-4-1968, p. 9). A interlocução com partidos e agrupações de esquerda, tanto em Montevidéu como noutras cidades uruguaias, colocou o sindicato diante de um novo dilema: como conjugar a exigência de uma "reforma agrária" com a prédica e o compromisso revolucionários? Em suma, como articular reforma e revolução? A chave para lidar com essa questão foi avaliar e problematizar as relações entre "peludo" e "camponês". Essa segunda categoria denotava, nos cartazes elaborados desde a marcha de 1964, o grupo de pessoas das quais Sendic era o líder: "Raúl Sendic, líder camponês". No Uruguai sessentista, a referência às Ligas Camponesas brasileiras, lideradas por Francisco Julião, e aos camponeses cubanos (guajiros) que aderiram ao Movimento 26 de Julho, povoavam o imaginário daqueles setores da esquerda urbana que, em meio à efervescência política continental, flertavam com o horizonte da insurreição popular. Nesse contexto, aderir à categoria de "camponês" significou, para os peludos da UTAA, uma promissora ponte de diálogo com as expectativas revolucionárias da esquerda nacional, o que favoreceu uma articulação estratégica com partidos e agrupações políticas capazes de oferecer todo o tipo de suporte às reivindicações agrárias do sindicato. No entanto, mais do que um emblema que os tornava legíveis 
no campo da esquerda, a categoria de "camponês" também parece ter sintetizado o tipo de radicalidade da qual os peludos se pretendiam portadores. Analisemos este ponto mais de perto.

Independentemente de seus usos econômicos ou sociológicos, o termo "camponês" encontrava-se disponível como sinônimo de rebeldia e insubordinação rural na América Latina dos anos sessenta. Sob o signo de Sendic, o "peludo da UTAA" estava autorizado, também ele, a ser um "camponês" porque se deixava arrastar pela violenta irreverência da aposta revolucionária: saía em busca de novos horizontes para experimentar sua potência agora que certa política havia anunciado a suspensão possível da dominação existente. Gallo, um peludo cuja militância sindical remontava às primeiras ocupações de fábricas em Bella Unión, no início dos anos 1960, escolhera colocar as coisas nos seguintes termos: "para aqueles que dizem que nós somos incapazes de fazer qualquer coisa sem ter um patrão em cima, estamos desejando provar que os trabalhadores se bastam de sobra para mandar nos campos e nas fábricas, não porque queiramos nos impor como mais fortes, mas porque sem nós nada poderia ser feito" (CUESTIÓN, 28-4-1971, p. 10). "Camponês" era apenas o nome de um devir radical sustentado pela afirmação política do peludo enquanto sujeito de possibilidades múltiplas. Paradoxalmente, o peludo era um assalariado rural desempregado que, transformado em “camponês" nas ruas conturbadas de Montevidéu, não queria assimilar-se ao campesinato e tampouco pretendia continuar sendo um assalariado. Tanto peludo como "camponês" pareciam ser os nomes de uma transição sem fim pré-definido. Numa esclarecedora entrevista concedida a Guillermo Chifflet em 1971, um "jovenzinho" que seus companheiros chamavam de "Brasilerito" rememorava sua resposta ao delegado de polícia quando este lhe pediu para explicar o que era um "assalariado rural":

- Eu disse assim: chamam-se assalariados rurais aqueles trabalhadores contratados por mês, por ano ou por dia que não têm terra, não têm ferramentas e só podem viver da sua força de trabalho [...] "Vá em frente", me diz [o delegado]. Daí eu digo assim: "o que tu estás pensando? Estás achando que um assalariado agrícola é um burguês com todo esse palavreado?" E assim eu meio que tirei um sarro dele, daí ele se abriu para mim...

- Te pediram documentos?

- Sim. Daí eu disse: não tenho papéis, não tenho documento de identidade, nem sei se eu represento alguma coisa aqui no Uruguai. Sei que nasci em Artigas ${ }^{17}$. (MARCHA, 30-4-1971, p. 22) (grifos meus)

Nessa definição, o marxismo popular harmoniza com o experimentalismo político da sequência agrária para dar origem a uma imagem majoritariamente "negativa" e não identitária do "assalariado rural". O assalariado é aquele que não tem terra, nem ferramentas, nem papéis

${ }^{17}$ Artigas é a capital do departamento homônimo, situado na fronteira com o Brasil, adjacente à cidade gaúcha de Quaraí. 
(documentos), mas que de qualquer modo existe, seja como força de trabalho no contexto das relações de produção ou - e isto é fundamental - como alguém que simplesmente nasceu em Artigas e decidiu "seguir em frente com os companheiros" (Ibidem). A dimensão afirmativa e criadora da condição social reivindicada pelo Brasilerito não residia na apresentação de uma exigência política pontual, mas sim na decisão de seguir em frente, junto aos demais, consciente de uma carência e convicto da possibilidade de transcendê-la através da luta.

Na última Marcha por la Tierra, em 1971, um dirigente sindical ponderava, durante uma entrevista à imprensa do movimento 26 de Marzo, atrelado ao MLN-T, que seria "um grave erro se a UTAA começasse a lutar para transformar todos os assalariados agrícolas do país em pequenos camponeses". Não estava em jogo, para o sindicato, a disputa pela propriedade individual da terra: "a UTAA parte da base de que a reivindicação da terra em geral pertence aos camponeses pobres e médios e não aos assalariados agrícolas" (CUESTIÓN, 28-4-1971, p. 10). No concernente aos peludos, se eles pudessem controlar algumas parcelas do latifúndio Silva y Rosas, instalariam ali a "Comunidad Tierra para Todos Lourdes Pintos, em homenagem a companheira caída na última marcha", onde, sem serem proprietários individuais da terra, "poderão trabalhar e comer todos os dias, desenvolver sua consciência de classe para lutar com efetividade buscando mudar as estruturas" (Ibidem). Conforme especificava o sindicato em seu jornal Tierra y Libertad: "A cooperativa [em referência à comunidade Tierra para Todos] por si só não pode levar adiante a luta pela mudança das estruturas". Pelo contrário, ela permanece constrangida "pela falta de créditos, ferramentas, assessoramento técnico" (Apud ROSSI, 2006, s.p.). Aparentemente, a "Comunidad Tierra para Todos" não era pensada enquanto um mecanismo de campesinificação do assalariado rural, mas sim como um lugar alternativo de trabalho onde, protegidos da pressão patronal, os trabalhadores cultivariam vínculos de solidariedade entre si e com a luta de seus companheiros.

Em 1970, o latifúndio Silva y Rosas foi parcialmente expropriado pelo Estado uruguaio, mas a UTAA jamais pôde dispor dessas terras para continuar desenvolvendo sua política. Em 1972, na antessala do golpe de Estado civil-militar, a repressão policial se havia acentuado como nunca no Uruguai. Nesse contexto, a sede da UTAA foi invadida e destruída pela polícia. Uma policlínica, erguida com muito esforço pelo sindicato durante os anos precedentes, também sofreu o mesmo destino e terminou sendo transformada na sede de um destacamento militar. Boa parte dos dirigentes e apoiadores da organização acabou detida pelo exército: a sequência agrária encontrava-se, agora, totalmente inviabilizada. Durante a ditadura militar (1973-1985), o Estado uruguaio pretendeu tornarse consubstancial a toda e qualquer expressão da política. Não havia, portanto, possibilidade de 
subjetivação sistemática da experiência repressiva ou dos mal-estares decorrentes das relações de produção por fora das categorias de enunciação legitimadas pelo governo autoritário. O terror erigiuse como um importante instrumento de eliminação das subjetividades políticas que desafiavam a ordem social assegurada pelo Estado. Graças ao terror, foi possível transformar até mesmo as mais tímidas manifestações da dissidência em objeto de administração repressiva através do estigma, da tortura, da prisão, do exílio e da desaparição. A prerrogativa da repressão como instrumento de administração da dissidência política só seria parcialmente impugnada com a redemocratização do país, mas isso não significaria um deslocamento imediato dos espaços de subjetivação circunscritos pelo terror.

Com a redemocratização do Uruguai, em meados dos anos oitenta, a repressão policial e a perseguição política arrefeceram. No entanto, o respeito à legalidade vigente - em cuja defesa os militares decretaram o estado de exceção - continuou sendo, agora com beneplácito dos setores majoritários da própria esquerda, o ponto de partida para qualquer diálogo sério sobre política. Após o retorno das tropas aos quartéis, foram as grandes forças político-partidárias do establishment democrático as encarregadas de promover uma sutura sistemática - amparada mais na persuasão coercitiva do que na repressão assassina - entre fabulação política, norma jurídica e rotinas administrativas. O tempo presente, construído sobre a derrota da experimentação social das décadas precedentes e sobre a deslegitimação das suas categorias de pensamento, é o tempo no - e contra o qual transcorriam as lutas da UTAA em 2015. Trinta anos depois do final da ditadura, poderíamos dizer que os rastros das sequências autonômicas prévias ao golpe de Estado de 1973 eram convocados pela militância popular do extremo norte uruguaio como parâmetros para pensar contra o terror, se entendermos esse último, essencialmente, como o efeito perene da negação a priori de qualquer política que não se pense, desde o início, em relação a sua própria viabilidade ou plausibilidade nos quadros institucionais já existentes.

\section{PALAVRAS FINAIS: DUAS ÉPOCAS, O MESMO TEMPO}

No âmago das autênticas lembranças, duas épocas se detêm uma ao lado da outra, ambas unidas por uma determinação em comum que as correlaciona imediatamente. Assim correlacionadas, as duas épocas ingressam num tempo novo, que é o tempo do que as conecta. Poderíamos, inclusive, falar de um tempo da autonomia que comporta entradas e saídas intermitentes. Cada entrada exige, para retomar os termos de Emilio, uma "mudança de ângulo"; uma nova forma de perceber o que 
somos capazes de ser e de fazer. A mudança de ângulo desestabiliza o fluxo da rotina e abre margem para uma atitude definitiva e divisória em relação às dinâmicas do cotidiano. Em 2015, isso implicava desvencilhar-se da "gestão" e aderir ao tempo da "luta", no qual era possível prescrever e exercer a mutabilidade de uma situação dada de acordo com critérios de ação que não estavam necessariamente previstos nas regras de jogo existentes. Entre 1964 e 1971, a "sequência agrária" também desenvolveu seu próprio tempo de experimentação política. Como vimos, esse tempo transcorreu sob as condições de uma prescrição que anunciava o devir "camponês" dos peludos no terreno de certa conversão revolucionária identificada com o nome de Raúl Sendic.

Foi o tempo da "luta", inaugurado em 2015, que viabilizou minha aproximação analítica ao processo autonômico subjacente às palavras "terra" e "Sendic". Certamente, a "luta" de 2015 postulava um conjunto de possibilidades que não eram as mesmas reivindicadas cinquenta anos antes, no transcorrer da "sequência agrária". Entretanto, levando em conta que a "luta" dos dirigentes da UTAA encontrava seu sentido essencial na suposição de uma atitude combativa outrora cristalizada, por exemplo, na palavra "terra", seria lícito dizer que essa mesma "luta" incluía, também, uma especulação sobre a origem política do vocábulo que a referenciava. Tal origem terá sido uma mudança de atitude análoga àquela que a militância sindical pretendia operar/replicar em sua própria conjuntura. "Luta" e "terra" tornam-se, então, os nomes de uma autonomia possível, condicionada pela invenção circunstancial de novos termos para encarar e desafiar os mal-estares da vida rotineira em qualquer conjuntura. Já do ponto de vista da análise sequencial dos processos políticos, o aparecimento da correlação "terra" - "Sendic" nas "autênticas lembranças" vivenciadas pela militância da UTAA em 2015 constituiu uma oportunidade para verificar e especificar a mudança de atitude que uma política contemporânea supõe em suas correlatas de tempos passados. A implicação fundamental desse procedimento é a descontextualização radical que ele autoriza.

$\mathrm{Na}$ análise sequencial, as palavras e nomes resgatados pelos protagonistas de uma política autonômica atual são revisitados em sua singularidade, o que implica fazê-los "saltar" de sua época e convidá-los a falar no interior de seu próprio campo de possibilidades. Abordar as palavras e os nomes no registro de sua singularidade é indagar pelo que eles permitiram prescrever, ou ainda, pela mudança de atitude que lhes subjaz e que foi declarada possível durante certo tempo - dias, meses, alguns anos. Devo observar que a identificação da sequência agrária constituiu um procedimento experimental e não exaustivo. Em nenhum momento almejei esgotar o inventário dos "possíveis" que outrora foram indexados às palavras "terra" ou "Sendic". Apenas indiquei que existem bons motivos para crer que esses possíveis realmente tiveram lugar. Se for assim, podemos dizer que as "autênticas 
lembranças" não inventam um passado que seja compatível com os interesses pontuais de quem as experimenta. Em vez disso, elas revelam as virtualidades de um passado que esteja à altura do processo político que as comporta. Cabe sugerir, portanto, que certos acontecimentos pertencem a uma duração cintilante, que se abre e se fecha de golpe, uma e outra vez. Sua "história" só seria captável no cruzamento dessas sequências intermitentes que configuram o tempo descontínuo da autonomia; um tempo cuja estrutura, nas palavras de Benjamin, é a de uma "detenção messiânica do acontecer ou, dito de outra forma, de uma chance revolucionária na luta pelo passado oprimido" (BENJAMIN, 2001, p. 51). Grifo no original.

Para Benjamin, no espaço da "detenção messiânica" se revela "um acordo secreto entre as gerações passadas e a nossa": "fomos esperados na terra. Tanto nós como as gerações que nos precederam possuem uma frágil força messiânica sobre a qual o passado tem um direito" (Ibidem, p. 43). Essa proposição enigmática parece ressoar naquela reflexão de Sandro segundo a qual "os velhos nos deram a ponta do fio e nós caminhamos, mas também fracassamos". Se "luta" era o que os militantes da UTAA se sentiam em condições de fazer uma vez que, à revelia dos fracassos, eles retomavam a ponta do fio entregue pelos velhos, então a análise sequencial da política é o que podemos dizer sobre a consistência desse fio à luz das premissas de quem o resgata do passado oprimido e o inclui entre as determinações de sua própria autonomia. A análise sequencial dos processos autonômicos proporciona, no final das contas, uma história possível do aparecer inconstante daquela "força messiânica" que uma luta reconhece em sua predecessora e se propõe a atualizar por si mesma, sob novos nomes e com consequências imprevisíveis.

\section{REFERÊNCIAS}

BENJAMIN, Walter. Discursos interrumpidos I. Filosofía del arte y de la historia. Buenos Aires: Taurus. 1989.

BENJAMIN, Walter. Tesis de filosofía de la historia. In: S. Verlag (org.), Ensayos escogidos. México: Ediciones Coyoacán. 2001. pp. 43-52.

BENJAMIN, Walter. Desenterrar y recordar. In: A. Mancini (org.), Cuadros de un pensamiento. Buenos Aires: Imago Mundi. 2013.

BLIXEN, Samuel. Sendic. Acción y Legado. Montevideo: Trilce. 2000.

CUESTIÓN. "UTAA culmina su quinta cruzada por tierra y libertad”. CUESTIÓN, (28-4-1971), pp. 9-11. 
GONZÁLEZ, Yamandú. Los olvidados de la tierra. Vida, organización y luchas de los sindicatos rurales. Montevideo: Nordam. 1994.

HALLWARD, Peter. The Politics of Prescription. The South Atlantic Quarterly, 104 (4), 2005, pp. 769-789.

HAYEM, Judith. The Voucher Strike: Workers Political Subjectivities in Post-Apartheid South Africa, Journal of Asian and African Studies, 47 (5), 2012, pp. 516-529.

KOHN, Eduardo. Infidels, Virgins and the Black-Robed Priest: A Back Woods History of Ecuador's Montaña Region. Ethnohistory, 49(3), 2002, pp. 545-582

TAUSSIG, Michael. 1995. Un gigante en convulsiones. Barcelona: Gedisa.

MARCHA. "De la rebeldía en adelante”. por Eduardo Galeano,1964. Marcha. (13-3-1964), p. 11

MARCHA. “La 'zurda' quiere trabar la marcha cañera”. Marcha. p.5. (9-4-1965)

MARCHA. “Miedo en el poder”. por Julio Castro e José Quijano. Marcha. (23-4-1965), p.8.

MARCHA. "Sin tierra y con dignidad”. Marcha. (18-4-1968), p. 11.

MARCHA. “Cañeros hoy”. Marcha. (26-4-1968), p.9.

MARCHA. “UTAA: la larga marcha”. por Guillermo Chifflet. Marcha. (30-4-1971), p.22.

ROSSI, Mario. 2006. $45^{\circ}$ Aniversario de la Creación de la Unión de Trabajadores Azucareros de Artigas (UTAA). Movimiento Revolucionario Oriental. Disponível em: http://www.mro.nuevaradio.org/?p=252 [Acesso 6 Abr. 2016].

SANTANA-PEREZ, Rubén. Memorias de un peludo. Montevideo: Nordan. Ethnohistory, 49(3), 2013, pp. 545-582.

LAZARUS, Sylvain. Anthropologie du nom. Paris: Editions du Seuil. 1996.

LAZARUS, Sylvain. Révolution, un mot singulier. Lignes, (4), 2001, pp. 97-107.

LAZARUS, Sylvain. L’intelligence de la politique. Paris: Al Dante. 2013.

MERENSON, Silvina. Los peludos: cultura, política y nación en los márgenes del Uruguay. Buenos Aires: Gorla. 2016.

MORAES, Alex. Antropología del desarrollo: entre la máquina anti-política y la máquina deseante. Trama, 6, 2015, pp. 23-32 
MORAES, Alex. Esfuerzo de lo posible. Política, desarrollo y deseo en el extremo norte del Uruguay (tese de doutorado). Universidad de San Martin, Escuela Interdisciplinaria de Altos Estudios Sociales, Departamento de Antropología Social, Buenos Aires, Argentina. 2019.

MORAES, Alex. Podemos pensar a política politicamente? As respostas de Bruno Latour e Sylvain Lazaros. Tempo da Ciência, 27(53), 2020, pp. 46-65.

MORAES, Alex. Lucha agraria y equipamiento colectivo de deseo en el contexto de la reactivación de la industria azucarera uruguaya. Un abordaje marxista-deseante. Cuadernos de Antropología Social, 53(2), 2021, pp. 199-215.

NEOCOSMOS, Michael. "Are Those-Who-Do-Not-Count Capable of Reason? Thinking Political Subjectivity in the (Neo-) Colonial World and the Limits of History". Journal of Asian and African Studies, 47(5), 2012a, pp. 530-547.

RAMOS, Ana. La memoria como objeto de reflexión: recortando una definición en movimiento. In: A. Ramos, C. Crespo y M. Tozzini (orgs.), Memorias en lucha: recuerdos y silencios en contextos de subordinación y alteridad. Viedma: Editorial UNRN. 2016. pp. 51-69.

RAMOS, Ana. Perspectivas antropológicas sobre la memoria en contextos de diversidad y desigualdad. Alteridades, 21(42), 2011, pp. 131-148.

ROSENCOF, Mauricio. La rebelión de los cañeros y los hombres del arroz. Montevideo: TAE. 1989.

SIBERTIN-BLANC, Guillaume. Coyuntura o acontecimiento: la subjetivación revolucionaria en Guattari, Althusser y Deleuze. Actuel Marx Intervenciones, (11), 2011, pp. 181-210. 